\title{
On Translation Strategies of the Epic Texts
}

\author{
Vilena G. Dyachkovskaya* \\ M.K. Ammosov North-Eastern Federal University \\ 58 Belinsky Str., Yakutsk, 677000, Russia
}

Received 15.02.2018, received in revised form 10.04.2018, accepted 24.04.2018

The paper deals with translation strategies of the epic texts in the case of the Sakha epic "Nurgun Botur the Swift" translation into English. Due to the variety of research works on the Sakha-Russian translation issues this paper focuses on the review of olonkho translations into other languages of the world. The framework theory includes the review of studies on translation strategies in Russia and abroad. As global translation strategies Lawrence Venuti's 'domestication' and 'foreignisation' are considered. The idea of "a golden mean strategy" is introduced. The paper views lexical translation challenges. Local strategies to overcome lexical challenges in the epic translation, as transliteration/ transcription, calque, partial calque, and explication occur to be the most applicable in the translation of the epic texts. Practical significance lies in the possibility of using the materials of this study by translators-practitioners in the translation of epic texts, in the courses on "Theory and practice of translation", "Literary translation" as well as in assessing the quality of translations.

Keywords: translation, epic; olonkho, translation strategies, domestication, foreignization, a golden mean strategy, global and local strategies.

DOI: $10.17516 / 1997-1370-0264$.

Research area: linguistics.

\section{Introduction.}

\section{Olonkho in the World's Languages}

Olonkho, a unique Sakha (Yakut) heroic epic, was proclaimed in 2005 a UNESCO Designated Masterpiece of the Oral and Intangible Heritage of Humanity. It has strongly marked specific genre features and sharply contrasts with other folklore genres in its ideological and thematic content, traditional range of images, stability of composition structure, originality of existence, olonkho performers' skills, and the traditional style and figures of speech (Emelyanov, 1980: 6).

Olonkho is considered to be a specific field of culture, which reflects the identity, the culture and the mentality of the Sakha people. Therefore, it is rich in culture-specific vocabulary, epithets, word pairs, picturesque words and other peculiarities that complicate the process of translation. Professional responsibility of the translator is to overcome translation challenges applying different strategies.

As noted by many olonkho researchers, the translation of the epic texts into the language of a different language group is extremely important and at the same time it is a difficult task. For instance, the Sakha language is of Altaic origin while the English language belongs to the IndoEuropean language family.

(C) Siberian Federal University. All rights reserved

* Corresponding author E-mail address: vildjach@yandex.ru 
The first time when the olonkho spoke in a foreign language was in a line-by-line translation into German in the appendix to the work of O. Boetlingk "On the Language of the Yakuts" (1851). The first translation of the olonkho into English was the translation of the olonkho of A.Ia. Uvarovskii "Er Sogotokh" carried out by Douglas Lindsey, an Associate Professor of Traumatic Surgery Department of Arizona University Medical College, and published in the quarterly edition of the University of Arizona in 1971. In 1984, Milos Krno translated the olonkho "Nurgun Botur the Swift" into the Slovak language. The author of several articles on the ethnography of Yakutia Yankel Karro together with L.M. Sabaraikina, a NEFU Associate Professor, translated K.G. Orosin's olonkho "Eles Botur" into French; he also translated a fragment of the olonkho "Nurgun Botur the Swift" of P.A. Oyunky for children. The first song of this olonkho was also translated into English by A.A. Skryabina in 1993 and by R.Iu. Skrybykin in 1995. In 2002, A.A. Skryabina made a fulltext translation of P.V. Ogotoev's olonkho "Eles Bootur". This olonkho was translated into French by a NEFU Associate Professor V.I. Shaposhnikova in 2015. In 2010, olonkho of K.G. Orosin "Nurgun Botur the Swift" spoke in Turkish, this work was performed by Murat Erzos. In 2014, "Nurgun Bootur the Swift" was translated into the Kyrgyz language by Sharshenaly Abdylbaev. A group of translators under the supervision of Doctor of Philology, Associate Professor A.A. Nakhodkina translated one of the most famous and voluminous olonkho of the Yakut folklore by P.A. Oiunskii "Nurgun Botur the Swift" into English in 2013.This is the full-text translation of the Yakut heroic epic into English. The publication was edited by Paul Norbury, Director of Renaissanse Books Publishing, Alina Nakhodkina, Doctor of Philology, Associate Professor, head of the NEFU
Translation Department, Geneviève Perreault from Canada, including Doctor of Philology Svetlana Johnston, a native from Yakutia, living in the UK. In 2016, V.K. Alekseeva translated the olonkho of D.A. Tomskaia - Chaika "Kyys Kylaabinai the Warrior"; in 2017 "Ogo Tulaaiakh" by V. Karataev and "Khaptaljin Baatyr" by S. Chernogradskii. It was edited by NEFU professor V.V. Illarionov.

As T.A. Kazakova notes, folklore texts represent a special difficulty as an object of translation. They are accompanied by a duality of choice, when the translator has to decide whether to preserve the specifics of the original formula in translation or to look for an analogue (Kazakova, 2006: 317). Hence, the issue of epic texts translation strategy appears to be of great importance.

\section{Studies on Translation Strategies in Russia}

Translation strategy is a term that different researchers understand differently. On the one hand, it is a cognitive process that involves translation procedures that occur in the mind of the translator, on the other hand, a strategy implicates various translation techniques, methods. The common factor is that strategy is used by translators to find solutions to translation problems and implementation of adequate translation in general.

Under the translation strategy, I.S. Alekseeva understands the order and essence of the translator's actions when translating a specific text. At the same time, she highlights the importance of differentiating the concepts of "translation actions" and "translation strategy". Translation actions, according to the researcher, refer to the whole set of possible actions for the implementation of translation, while translation strategy is the consciously chosen algorithm of these actions by the translator when translating 
one particular text (or group of texts) (Alekseeva, 2008: 329).

I.S. Alekseeva describes in detail three stages of translation strategies: pre-translation analysis, proper translation and post-translational processing of the text. A pre-translation analysis includes the collection of external information on the text, the definition of the source and the recipient, its communicative task and genre. Proper translation is a "search": the translator goes "analytically", each time "commenting on his actions and explaining the reason". The last stage is an analysis of the results of the translation and includes technical work on the translation text. The translator should evaluate the unity of his style without comparison with the original text, i.e. proofreading (Alekseeva, 2008: 333-342).

V.N. Komissarov gives several points that determine the choice strategy: the nature of the source text (Komissarov, 2002: 72); the degree of prestige of the foreign author in the host culture; genre of literary work (Komissarov, 2002: 70). V.N. Komissarov also emphasizes the importance of socio-cultural influence on the translation strategy, which is often reflected in the completeness of the translation of the original, forcing the translator to reduce or completely omit the unacceptable in the receiving culture (Komissarov, 2002: 74).

L.G. Shereminskaia also applies the term "translation strategy". She argues that mastering the correct strategy of the translation process is an important condition for the effectiveness of translation activities. It is based on a number of fundamental principles that are used at the conscious or unconscious level by each professional translator depending on the specific conditions of the translation action. Firstly, translation strategy, according to Shereminskaia, is an understanding of the subject, which is a necessary condition for achieving a good result. Secondly, it is the ability to determine the semantic dominant, the most important part of the content of the translated statement. The basic principles of the translation strategy are supplemented by the justification for the validity of a number of techniques (Shereminskaia, 2008: 62-64).

T.A. Kazakova draws attention to the fact that communicative success to a great extend depends on how correctly the translator chooses the method of translation, applies the appropriate strategy and determines the units of translation (Kazakova, 2001: 11). Although the researcher does not give the definition of the term, she indicates that in the semantic translation two strategies naturally interact: a strategy oriented towards the method of expression accepted in the target language, and a strategy focused on preserving the features of the original form of expression (Kazakova, 2001: 14).

In Russian translation studies, A. D. Schweitzer was one of the firsts to use the term "translation strategy". He points out that translation, in general, consists of a series of choices. At the first stage, the translator faces a choice of a translation strategy, which includes, first and foremost, the decision of translator to give preference to either a textually accurate (literal) translation or a translation greatly deviating from the formal structure of the source text, close to free. Afterwards, the translator decides on the aspects of the original, which must be reflected in the TT primarily. Thereby he creates a certain hierarchy of values, organizes prioritizes (Schweitzer, 1988: 65).

A.D. Schweitzer's and T.A. Kazakova's dualism is close to two strategies of American translation theorists L. Venuti.

\section{Studies on Translation}

\section{Strategies Abroad: Domestication and Foreignization}

In 1995, L. Venuti published a monograph “The Translator's Invisibility”, where he first used 
the terms "domestication" and "foreignization", denoting the two main strategies by which the translator is guided in solving linguistic and cultural issues.

Considering the translation strategies, L. Venuti introduces the concept of "invisibility" of the translator. L. Venuti defines the main characteristics of the translated text as ease of perception, i.e. the text is easy to read, and transparency, i.e. the text reflects the personality and intentions of the author, as a result, it seems that we read the original, not the translation. In this case, as L. Venuti emphasizes, the more easily the translation is read, the more invisible the translator is, and the more visible the author of the original is. Thus, the main characteristics of the translation strategy of domestication, according to L. Venuti, are fluency (ease of perception), transparency (transparency) and, as a consequence, the "invisibility" of the translator.

As for the translations made in accordance with the translation strategy of foreignization, in this case certain "opacity" of the text arises, and the so-called "dark places" appear in it, the translator becomes "visible". This text is read as a translation (Venuti, 1995).

According to Venuti, domestication is an ethnocentric approach, in which the original text is often reduced, the emphasis is on the cultural values of the target language, and the author is approaching the reader; foreignization is an approach in which the emphasis is on preserving foreign linguistic and cultural values, while "the reader is approaching the author". In a broad sense, domestication implies a "transparent", easy-to-understand style, due to which the foreign text appears less strange to the reader. In the case of foreignization, the text of the translation violates some generally accepted norms of the translation language, preserving the features of the original text.

Venuti believes that domestication is aimed at compelling the target text to sound familiar to dominant culture and to express the concepts that are habitual for it. The strategy of domestication presupposes an ethnocentric approach, in which the source text is reduced and changed to suit the linguistic culture of the translation, which reflects the Eurocentric and, specifically, the Anglo-centric trend of the era of imperialism. The opposite approach, in its turn, leads to the need to eliminate the smoothing of the distinctive features of the foreign text.

Thus, domestication strategy makes the translator "invisible", merely omitting notions and phenomena that require additional explanation, or replacing them with similar cultural phenomena of the target language. It contrasts with foreignization strategy, in which the translator becomes "visible", explaining and commenting on the untranslatable features of the foreign language text and culture (Venuti, 1995). There we would point out in advance that in the case when a translator seeks a "golden mean"; his "visibility" can be felt differently in different parts of the text.

Foreignization involves application of translation methods emphasizing the distinctive features of the culture of the source text that the culture of the target language lacks. As a result, the translated text does not resemble either the original text or any other text in the target language. With foreignization, the reader is approaching the culture of the original (Venuti, 1995).

Venuti indicated that it is preferable for the translator to reduce ethnocentric compulsion when translating. The strategy of foreignization allows limiting the forced "domestication" of world cultural values by the English-speaking part of the world. Thus, foreignization is aimed at emphasizing the features of the original text, and not hiding the "presence of a translator". This will ensure protection from the ideological pressure of the culture of the dominant language 
of translation. According to Venuti, domestication and foreignization are heuristic concepts. Their poles in translation vary depending on the time and status of the countries of the original texts and the translation. However, the fact that accentuation or ignoring the cultural peculiarities of a particular foreign language is due to the dominance/subordination of its culture in the world at the specific momentremains unchanged (Venuti, 1995).

\section{Global and Local Strategies}

As it was mentioned above, free and literal translations distinguished by Russian translation researchers may correlate with Venuti's strategies of domestication and foreignization. L.K. Latyshev, along with these two types of translation, distinguishes a "proper translation", which in its turn can be referred to as "the golden mean strategy". He writes that the proper translation is to a certain extent a hybrid of literal and free translations. From the literal, it took an orientation toward the maximal semanticstructural closeness to the original text, but only where it is possible, and does not lead to a violation of the norms of the target language, does not create ambiguities and inadequate perception of the addressee (Latyshev, 2003: 17).

Indeed, in the modern translation practice, foreignization and domestication are extremely rare; none of the translations represent one or the other method "in its pure form". The third translation strategy, the so-called the golden mean strategy, is a successful combination of the two translational directions. In fact, each time it is a combination of opposing translation strategies. After all, simultaneous use of opposing translation methods leads to what is called the "golden mean", and ensures the achievement of artistic accuracy.

Translator's choice of one or another strategy (foreignization, domestication, golden mean strategy) is called a global strategy, whereas local strategies deal with translation challenges that arise directly in the translation process. Such strategies can be seen as translation transformations, methods, or means. Table 1 presents the distribution of the most popular and frequent local strategies to overcome the lexical problems of translation by global strategies.

\section{Most Common Lexical Challenges of the Epic Translation}

The goal of the epic translation is not only to introduce a new culture and language of the source text to a foreign reader, but also to make the epic a heritage of world culture, which in its turn will contribute to raising the prestige of the whole ethnicity. Therefore, it is necessary to make the text interesting and readable. In other words, we believe the golden mean strategy to be an ideal strategy for epic texts translation. But what are the actual facts?

This paper studies some lexical aspects in the translation of the heroic epic "Nurgun Botur the Swift" by A.A. Nakhodkina (Oiunskii,

Table 1

\begin{tabular}{|l|l|l|}
\hline \multicolumn{1}{|c|}{ Foreignization } & \multicolumn{1}{|c|}{ Golden Mean } & \multicolumn{1}{c|}{ Domestication } \\
\hline Transcription & Explication & Modulation \\
Transliteration & Compensation & Adaptation \\
Calque & Transposition & Omission \\
Translation commentary & Addition & Functional substitution \\
& & Generalization \\
\hline
\end{tabular}


2014) in comparison with the first translation of the same olonkho carried out by a teacher of English R.Iu. Skrybykin, Republican College in Yakutsk (Skrybykin, 1995). The overview of the research works on the translation of the particular epic and comparative analysis of the source text and the texts of the translation revealed certain peculiarities.

As for A.A. Nakhodkina's translation, it is remarkable that all the translators of "Nurgun Botur the Swift" are native speakers and the translation was done without an intermediary language. The goal of the translators was to make the reader carry through all the uniqueness and richness of the heroic epic, without piling up the text with difficult to perceive unfamiliar vocabulary. As A.A. Nakhodkina writes, her "goal was not to put off the English-speaking reader but to inspire them to go on reading this long poem" (Nakhodkina, 2014: 277).

What is the greatest difficulty in translating Sakha epic texts into English? These are mostly lexical problems that can be seen as challenges translator has to overcome. As the most ancient epic art of the Sakha people it is full of archaisms, culture-specific vocabulary, figurative words, word pairs, realities etc.

Translation of proper names, as well as other realias, occurs to be a tremendous task for a translator. In the epic "Nurgun Botur the Swift" proper names are mainly transcribed.
Of particular value in this case are the works by A.A. Nakhodkina (Nakhodkina, 2014), as well as Z.E. Tarasova's Doctor's thesis "Phonological and phonosemantic aspects of the Yakut epic texts translation (into Russian and English)" (2013). The researchers introduce a table of practical transcription, not only from Sakha into English but also from Sakha into Russian. We believe that this table can gain widespread acceptance in the translation practice.

The comparison of two translation variants is also of great interest. The name Ньургун Бoomyp occurs in R.Iu. Skrybykin's (1) as Njurgun Bootur ['ndzə:g(ə)n bu:'tə], while in A.A. Nakhodkina's (2) variant we find Nurgun Botur ['nə:g(ə)n botə:]. A.A. Nakhodkina's combination of sounds even from the visual point of view is more convenient and attractive for the English-speaking reader, in contrast with translations of R.Yu. Skrybykin that causes some difficulties in pronunciation and therefore slows down further reading. Also compare the following examples: Үрүң Аар Тойон - Jurung

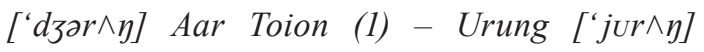
Aar Toyon (2); К Күн Өркөн - Kjun Ojrkjon [keid3^n oir'kion] (1) - Kun Erken [kun 'a:kən] (2); Өлүу Чөркөчөөх - Oljuи Chorkochokh [ol'dzu: 'tfo:kotfok] (1) - Eluu-Cherkechekh [el'ju: 'tfa:kət/ək] (2). Nevertheless, it should be taken into consideration that R.Iu. Skrybykin's translation was based on the experience of the

Table 2

\begin{tabular}{|c|c|c|}
\hline $\begin{array}{l}\text { Күлэр күөх салгыннаах, } \\
\text { Күндүл күнүс дойдулаах, } \\
\text { Үрүмэтийбит үүт күөллээх, } \\
\text { Үрүн илгэ үктэллээх, } \\
\text { Үкээр куйаас тыыннаах, } \\
\text { Үүт-aас бэйэкэлээх... } \\
\text { (Oiuunuskai, 2003: 12) }\end{array}$ & $\begin{array}{l}\text {...whose breathing was hot... } \\
\text {...where the air was blue and } \\
\text { caressing. } \\
\text { He inhabited in the dwelling-place } \\
\text { of a light midday, } \\
\text { with a serene lake near it. } \\
\text { He walked, treading on white clouds, } \\
\text { which were bringing abundance. } \\
\text { (Skrybykin and Oiuunuskay, 1995: 11) }\end{array}$ & $\begin{array}{l}\text { Where the air was light and blue, } \\
\text { The sunny midday land was there, } \\
\text { The creamy, milky lake was there. } \\
\text { Each step he took brought him an } \\
\text { ilgeh blessing, } \\
\text { His breath was hot, } \\
\text { He had plentiful supply of food, } \\
\text { He lived surrounded by abundance... } \\
\text { (Nakhodkina and Oyunsky, 2014: 6) }\end{array}$ \\
\hline
\end{tabular}


Yakut-Russian translation that was established in the late $19^{\text {th }}$ century.

The Sakha epic is rich in comparisons, metaphors, hyperboles, and epithets. They give the narrative a special colour and expressiveness. Most common are the epithets to the names of heroes, as well as to the descriptions of deities and worlds. These epithets sometimes contain an entire characteristic.

This fragment describes the place where the supreme deity of the Upper World Urung-Aar Toyon lives. First of all, we should pay attention to the fact that R.Iu. Skrybykin does not allocate the beginnings of lines across the whole text. However, in the original text each line is marked by capital letters.

Omission is found frequently in R.Iu. Skrybykin's olonkho. For instance, in this fragment a culture-specific word ilgeh (transcription of the term by Nakhodkina author) is omitted. This word means "divine bestowed by the gods". In the second variant the word is transliterated and given with explanation blessing. The epithets to the lake that is given in the first variants as serene that means "peaceful and calm" does not refer to the Sakha words УрУмэтийбит $Y Y$ ([ürümətijbit ü:t] - author). The lake here is described as "foamed and milky". The second variant creamy, milky lake is more appropriate. Word pairs are also of great interest. $Y_{Y m-a a c}$ ([ü:t a:s] - author) is litteraly translated as "milk and food". It is known that milk and milk products played a great for the Sakha people because their life depended directly on the cattle. The more cattle you had, the richer and wealthier you were. That was the reason why the translator of the second variant expanded the word pair YYm-aac and used the means of addition: He had plentiful supply of food, He lived surrounded by abundance.

When translating from the Sakha language into English, the translator encounters the fact that the English-speaking tradition lacks many concepts associated with the mythology and religion of the Sakha people. Therefore, an explication is an obligatory component of the epic translation. This allows conveying the meaning of everyday realias, the realias of the world and nature, mythological places, and representatives of mythological communities. A.A. Vasilyeva points out that in the translation of the epic texts different types of explication are commonly used. They can be divided by localization in the text:

1) in the translation text, next to realia;

2) outside the translation text, with reference to the select glossary of nontranslated words or translation commentaries, which contain a detailed interpretation of the realia, additional information on this concept;

3) without a reference word - the translation of a culture-specific word without the use of exoticism (Vasilyeva, 2011: 110).

The translation of A.A. Nakhodkina tends to preserve culture-specific words. Therefore, the first type of explication when the words are accompanied by their English equivalents appears many times. For instance, "seleh rope", "kekhe hooks" (long hook fixed in the Yakut balagan house to hang clothes, kitchen ware, etc.), "choroon goblets", "matachakh vessels" (wooden vessels for keeping dairy food); "bagakh post" (a sacred post to which a sacrificial animal is tethered, or hung with the skin of such animal). As a result we have attributive word combination where nucleus is expressed by the English equivalent and the transliterated culture-specific element as an attribute.

Translation of epic texts is impossible without translation comments. It is known that a translation comment is a strategy of foreignization, since it makes the translator visible to the reader. It is a way to compensate for the loss in translation and provides additional information that cannot be integrated into the 
general translation text. It is used for the culturebearer to understand and feel the peculiarities of the other. A translation comment, usually given in the form of footnotes or comments, provides additional information that cannot be integrated into the general translation text. This second type of explication is also used by A.A. Nakhodkina, whereas R.Iu. Skrybykin's version does not contain footnotes; some explications of unknown to the English-speaking reader phenomena are given after the text.

It is worth emphasizing that sometimes commentaries can be presented with some photos that illustrate in detail the most archaic realities.

The third type of explication, the translation of a culture-specific word without the use of exoticism, is of rare occurrence in A.A. Nakhodkina's translation. For example, the word арбађ $а c$ denoting 'a coat with shabby, faded fur' is translated as worn-out, ragged fur coat. It does not have an equivalent in the English language, so the translator opts to using the explication, thus achieving a better understanding.

To create meaningful units in the translated text and to preserve the elements of the form or function of the original unit, the method of calque is used. For instance, the names of the three worlds of olonkho are translated by the calque: Аллараа дойду (Нижний мир) - the Under World, Yөhээ дойду (Верхний мир) - the Upper World, Opmo дойду (Средний мир) - the Middle World.

Partial calque of words and word combinations, consisting partly of the elements of the source language, partly from the elements of the language of the receiver, also commonly occurs. The combination of transliteration and calque is used in the translation of names of mythological heroes, containing semantic components, reflecting some of their real qualities. For instance, Улуутуйар Улуу Суорун Тойон - Great Uluutuyar Uluu Sorun Toyon; К Кн тойон - the Sun - Kun Toyon; Бй хотун - the Moon - Yi Khotun; Чолбон тойон - The Venus Cholbon Toyon; Үргэл тойон - the Pleiades Urgel Toyon.

\section{Conclusions}

Translation demands a deep understanding and a solid knowledge of both languages and cultures. Olonkho represents the ideas, the language and the philosophy of the Sakha people. Undoubtedly, olonkho should be studied, printed, translated into the languages of the world. This is one of the ways of our epic to become the property of world culture, and this in turn will contribute to raising the prestige of our entire ethnicity.

Translation work requires meticulousness. The translator must be competent, have a good knowledge of vocabulary of both the source and target languages and consult dictionaries, thesauruses and other reference books to find the appropriate terms.

The golden mean strategy can be considered ideal for translation epic texts. To be critical, the strategy should tend more towards foreignization than domestication. In the case of domestication, the epic will lose all its colorfulness and expressiveness. After all, the translation of the olonkho is the contribution of the Sakha people to the treasury of the world culture. Olonkho reflects a rich fantasy, a great idea of infinity, the triumph of life over death, and the translator's duty to bring all this to the reader as preserved as possible. Still, each translation job is unique and the choice of domestication, foreignization or golden mean as translation strategy depends on a concrete case and on the translation goal.

As it was mentioned previously, I.S. Alekseeva defines three stages of translation strategies: pre-translation analysis, proper translation and post-translational processing of the text. Regarding translation stages/strategies of the 
epic texts we can distinguish the following: firstly, the pre-translation analysis, which implies the search for extralinguistic information, studying linguistic, cultural and ethnic peculiarities, the identification of cultural and linguistic realities, etc.; secondly, the definition of main difficulties in translation (phonetic, phonosemantic, semiotic, syntactic, etc.); thirdly, the proper translation with maximum preservation of the identity of the text, with an accurate transfer of the semantic content of the olonkho in compliance with the norms of translation; fourthly, technical work on the translation product including proofreading, check for collocations and grammar issues by a native speaker.

Life does not stand still, the translation is developing. It is delightful that every year thetranslations of olonkho into the languages of the world become more. As we have seen, the quality of translation is also growing.

\section{References}

Alekseeva, I.S. (2008). Vvedenie v perevodovedenie [Introduction to translation study]. SaintPetersburg, Akademiia, $368 \mathrm{p}$.

Emelyanov, N.V. (1980). Siuzhety iakutskikh olonkho [Sakha olonkho plots]. Moscow, Nauka, 376 p.

Kazakova, T.A. (2006). Khydozhestvennyi perevod [Literary translation. Theory and practice]. Saint-Petersburg, In“iazizdat, 544 p.

Kazakova, T.A. (2001). Prakticheskie osnovy perevoda English $<->$ Russian [Practical basis of translation English $<->$ Russian]. Saint-Petersburg, Soiuz, 320 p.

Komissarov, V.N. (2002). Sovremennoe perevodovedenie [Modern translation study]. Moscow, ETS, $424 \mathrm{p}$.

Latyshev, L.K. (2003). Perevod: teoriia, praktika i metodika prepodavaniia [Translation: theory, practice and teaching methods]. Moscow, Akademiia, $192 \mathrm{c.}$

Nakhodkina, A.A. (2014). Problems of (Un)translatability in the Yakut Epic Text Olonkho, In Journal of Siberian Federal University. Humanities \& Social Sciences. 2 (7), 273-286.

Nakhodkina, A.A. in Oyunsky, P.A. (2014). Nurgun Botur the Swift. London, Renaissance books, $516 \mathrm{p}$.

Oiuunuskai, P.A. (2003). Duluruyar Nurgun Bootur. Yakutsk, Sakhapoligrafizdat, 2003, 544 p.

Schweitzer, A.D. (1988). Teoriia perevoda: status, problem, aspekty [Translation theory: status, problems, and aspects]. Moscow, Nauka, $215 \mathrm{p}$.

Shereminskaia, L.G. (2008). Nastol'naia kniga perevodchika [Translator's handbook]. Rostovna-Donu, Feniks, 252 p.

Skrybykin, R.Iu. and Oiuunuskay, P.A. (1995). Njurgun Bootur the Impetuous. The First Song. In Vestnik respublikanskogo kolledzha. Filolologiia [Bulletin of the Republican College], (1), 6-110.

Vasilyeva, A.A. (2011). Osnovnye priiomy iakutsko-resskogo perevoda [Basic techniques of Yakut-Russian translation], In Vestnik SVFU [Vestnik of North-Eastern Federal University]. 8 (2), 105-112.

Venuti, L. (1995). The Translator's Invisibility. A History of Translation. London and New York, Routledge, $353 \mathrm{p}$. 


\title{
К вопросу о стратегиях перевода \\ эпических текстов
}

\author{
В.Г. Дьячковская \\ Северо-Восточный федеральный университет \\ им. М.К. Аммосова \\ Россия, 677000, Якутск, ул. Белинского, 58
}

\begin{abstract}
В статье рассматриваются стратегии перевода эпических текстов на материале перевода якутского героического эпоса "Дьулуруйар Ньургун Боотур» на английский язык. Во введении дается краткая история переводов олонхо на языки мира. В теоретической части представлен обзор исследований по вопросам стратегий перевода в России и за рубежом. В качестве глобальных стратегий перевода рассматриваются «доместикация» и «форенизация», введенные Лоуренсом Венути, а также стратегия «золотой середины». Особое внимание уделяется лексическим проблемам перевода. Наиболее частотныли локальными стратегиями преодоления лексических проблем в эпическом переводе являются транслитерация/транскрипция, каль-

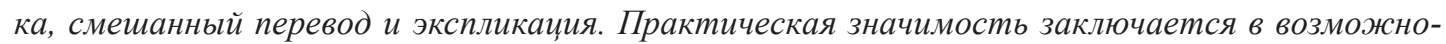
сти использования материалов данного исследования переводчиками-практиками в переводе эпических текстов, на курсах по «Теории и практике перевода», "Художественному переводу» и при оценке качества выполненных переводов.
\end{abstract}

Ключевые слова: перевод, эпос, олонхо, стратегии перевода, форенизачия, доместикация, стратегия золотой середины, глобальные и локальные стратегии.

Научная специальность: 10.02.00 - лингвистика. 